удк $004.4+378$

DOI 10.31494/2412-9208-2019-1-2-160-169

THE EXPEDIENCY OF INTRODUCING “EDUCATION TECHNOLOGIES AND LEARNING IN THE DIGITAL AGE" COURSE INTO EDUCATIONAL PLAN OF THE FUTURE PROFESSIONALS OF INFORMATION TECHNOLOGIES

\title{
ДОЦІЛЬНІСТЬ ВВЕДЕННЯ ДИСЦИПЛІНИ “ОСВІТНІ ТЕХНОЛОГІЇ ТА НАВЧАННЯ В ЦИФРОВУ ЕПОХУ" У ПРОЦЕС НАВЧАННЯ МАЙБУТНІХ ФАХІВЦІВ 3 ІНФОРМАЦІЙНИХ ТЕХНОЛОГІЙ
}

TETIANA VAKALIUK,

Candidate of Pedagogical Sciences,

Associate Professor
ТЕТЯНА ВАКАЛЮК, кандидат педагогічних наук, доцент

https://orcid.org/0000-0001-6825-4697

tetianavakaliuk@gmail.com

ANDRII MOROZOV,

Candidate of Engineering Sciences,

Associate Professor
АНДРІЙ МОРОЗОВ, кандидат технічних наук, доцент

https://orcid.org/0000-0003-3167-0683

morozov.andriy@gmail.com

ANDRII YEFIMENKO,

Candidate of Technical Sciences
АНДРІЙ ЄФІМЕНКО, кандидат технічних наук https://orcid.org/0000-0003-2128-4797 yefimenko.andrii@gmail.com

DMYTRO ANTONIUK,

Candidate of Pedagogical Sciences https://orcid.org/0000-0001-7496-3553

dmitry_antonyuk@yahoo.com

Zhytomyr Politechnic State University

$\triangle 103$, Chudnivska St.,

Zhytomyr, 10005, Ukraine
ДМИТРО АНТОНЮК, кандидат педагогічних наук

Державний університет "Житомирська політехніка" $\triangle$ вул. Чуднівська, 103, м. Житомир, Україна, 10005

Original manuscript received: July 17, 2019

Revised manuscript accepted: September 20, 2019

ABSTRACT

The article analyzes international experience of the diverse set of aspects of education technologies and digitalized education study at the higher education establishments. Carnegie Mellon University offers "Master of Educational Technology 
and Applied Learning Science" program for graduated bachelors. "Design educational games" is one of the examples of the courses offered. Stanford graduate School of Education offers "Education, design and technologies" course. Stanford University offers "Creating effective online and blended courses". University of Maryland provides set of courses, such as "Instructional Design: Digital Media, New Tools and Technology". Pennsylvania University offers "Introduction to Online and Blended Teaching". Massachusetts Institute of Technologies offers "Design and Development of Educational Technology".

The analysis of international experience led to the conclusion, that "Education technologies and learning in the digital age" course is reasonable to introduce into educational plan of the technical specialties' students and future professionals of information technologies in particular. The reasons to introduce the course for the future professionals of information technologies are the possibility to design and implement course and diploma works in the educational area (educational software development, educational games development, etc.), work at the educational software development companies, conduct PhD research in the area of educational technologies. The course prepares students to the future life-long learning using educational technologies. "Education technologies and learning in the digital age" course is oriented to the 121 "Software engineering", 122 "Computer science", 123 "Computer engineering, "125 "Cybersecurity", 126 "Information systems and technologies" and is based on the learning the main terms and principles of the education technologies and digital age education approaches. The approximate list of topics to learn in the course is provided. The advantages of the introducing the course are discussed.

Keywords: education technologies, EduTech, digital age, education, digitalization of education, higher education establishments.

Вступ. Нині в Україні у зв'язку з входженням у світовий інформаційний простір, швидкими темпами впроваджуються новітні досягнення педагогічної науки та інформаційно-комунікаційних технологій, унаслідок чого відбувається швидка інформатизація освіти.

Як зазначає В. Биков, пріоритетом в процесі інформатизації освіти $€$ формування інтелектуального потенціалу нації, двигуна наукового й соціально-економічного розвитку суспільства (Биков, 2003: 504-505). Реалізація цього можлива за умови розв'язання ряду завдань, серед яких виділимо окремі: "модернізація змісту і технологій навчання, які б відповідали сучасним освітнім пріоритетам, максимально використовували переваги ІКТ для підвищення якості освіти дітей, збереження здоров'я учнів; ... фрормування, постійне розширення освітнього інфоормаційного простору та спектру інформаційних ресурсів освіти, реалізація в освітньому інформаційному просторі всіх зв'язків і забезпечення необхідних комунікацій між учасниками навчального процесу, навколишнім середовищем; ... розробка нормативної бази, створення системи проєктування і управління процесом інформатизації; забезпечення якості, стандартизації й сертифрікації засобів ІКТ в освіті; інформатизація процесу управління освітою" (Биков, 2010).

Саме тому розвиток і впровадження електронних засобів навчання в усі галузі підготовки фрахівців набуває все більшого значення. Передумовою для цього є створення потужної інфраструктури (технічної та інфрормаційної) закладів освіти із розвиненим освітнім електронним 
середовищем, а також використання різного виду електронних засобів навчання.

Освітній процес, який організовано з використанням різних інформаційно-комунікаційних технологій та електронних засобів навчання, сприяє розвитку самоосвіти та особистісному зростанню в студентів

Різні аспекти інформатизації освіти висвітлюють В. Биков (Биков, 2008), А. Гуржій (Гуржій, 2013), М. Жалдак (Жалдак, 1991), Ю. Жук (Жук, 1998), Н. Морзе (Морзе, 2003), С. Семеріков (Семеріков, 2015), О. Спірін (Спірін, 2009), Ю. Триус (Триус, 2005), С. Яшанов (Яшанов, 2015) та ін. У своїх працях вони досліджують питання інформатизації освіти в закладах загальної середньої та вищої освіти. Проте питання доцільності введення дисципліни "Освітні технології та навчання в цифрову епоху" у процес навчання майбутніх фрахівців 3 інформаційних технологій нині не розглядалось вітчизняними науковцями.

Саме тому метою та завданням статті $\epsilon$ аналіз закордонного досвіду вивчення освітніх технологій та обґрунтування доцільності введення дисципліни “Освітні технології та навчання в цифрову епоху” у процес навчання майбутніх фахівців з інформаційних технологій.

Методи та методики дослідження. У процесі дослідження були використані такі методи:

- аналіз, систематизація, узагальнення психолого-педагогічної, спеціальної та методичної літератури з проблем вивчення освітніх технологій у зарубіжних закладах вищої освіти з метою виокремлення актуальних напрямів дослідження;

- метод конкретизації та систематизації теоретичних знань для розробки завдань дослідження;

- праксиметричний метод для аналізу педагогічного досвіду вивчення освітніх технологій у зарубіжних закладах вищої освіти.

Результати та дискусії. Вимогою часу та темпу розвитку суспільства є дослідження й використання переваг освітніх інформаційнокомунікаційних технологій (IKT). 3 цією метою освітні та наукові установи поєднують досягнення педагогічної науки та інформаційні технології.

Аналізуючи світовий досвід вивчення освітніх технологій, було встановлено наступне.

Carnegie Mellon University (https://metals.hcii.cmu.edu/) пропонує для випускників бакалаврату магістерську програму "Магістри освітніх технологій та прикладних навчальних наук" (https://metals.hcii.cmu.edu/curriculum/), де вивчаються: індивідуальне онлайн-навчання, дизайн навчальних ігор, прикладне машинне навчання, обчислювальні моделі аналізу дискурсу, проектування та інженерія інтелектуальних інформаційних систем, роль технологій у навчанні в 21 столітті, інтерактивна наука даних, взаємодія людини 3 Шا, теорія навчальних наук та навчальний дизайн, дизайн навчальних ігор, соціальні мережі, розширений веб-дизайн, проектування програмного забезпечення, орієнтованого на людину тощо. 
Зокрема, при вивченні дисципліни "Дизайн навчальних ігор" (https://hcii.cmu.edu/courses/design-educational-games) студенти готуються створювати ігри, які є і веселими, і в той же час навчальними, поєднуючи процеси та принципи дизайну ігор та інструктивного дизайну. Цей курс передбачає значну практичну частину, в рамках якої студенти засвоюють процес проєктування для створення навчальних ігор - цифрових чи не цифрових. Вони також дізнаються про наявні навчальні ігри та обговорять ігровий дизайн, навчальний дизайн, навчання та передачу, а також навчальну ефективність цифрових ігор.

\section{Carnegie Mellon University
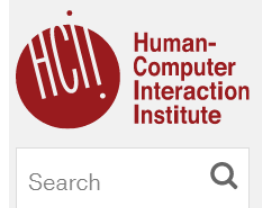 \\ $>$ Academics \\ $>$ Research \\ $>$ News \& Events \\ $>$ People \\ Facilities \\ Giving \\ About \\ Careers \\ Design of Educational Games

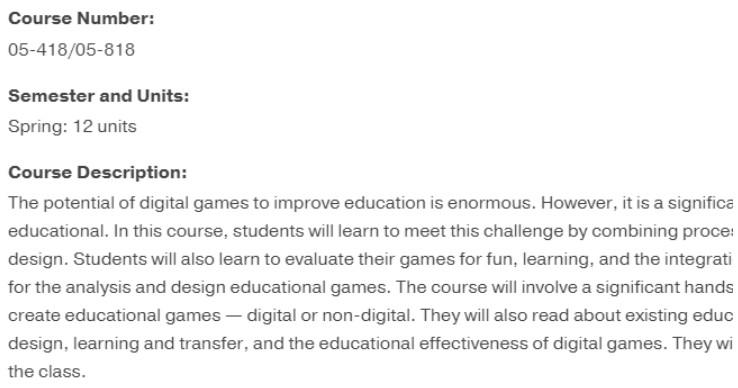

The potential of digital games to improve education is enormous. However, it is a signific $\varepsilon$ educational. In this course, students will learn to meet this challenge by combining proce: design. Students will also learn to evaluate their games for fun, learning, and the integrati for the analysis and design educational games. The course will involve a significant hands create educational games - digital or non-digital. They will also read about existing educ design, learning and transfer, and the educational effectiveness of digital games. They wi the class. \\ The intended audience includes graduate and advanced undergraduate students in HCI, psychology research.}

Pис. 1. Carnegie Mellon University. Курс "Дизайн навчальних ігор"

Stanford graduate School of Education пропонує для вивчення курс "Навчання, дизайн та технології" (https://ed.stanford.edu/academics /masters-handbook/program-requirements/ldt), під час якого вивчаються:

- методи оцінки та досліджень - засвоюється аналіз даних та якісні методи дослідження,

- процес проектування - взаємодія людини та комп'ютера, досвід навчання, допоміжні технології,

- навчання - розглядаються навчальні середовища, механізми навчання, навчання у формальному та неформальному середовищі, інженерна освіта та онлайн навчання

- дизайн досвіду навчання - розглядається побудова навчальних програм, розвиток дитини та нові технології тощо. 


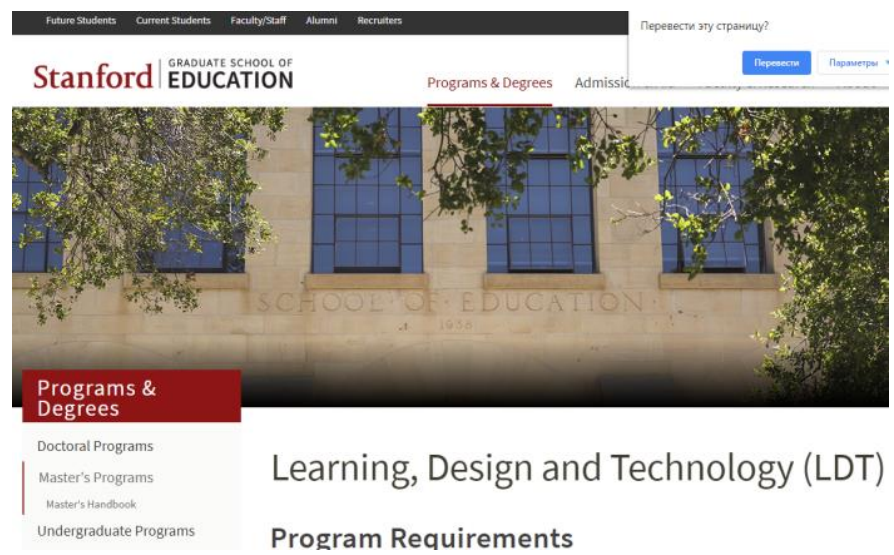

Рис. 2. Stanford graduate School of Education. Курс "Навчання, дизайн та технології"

Університет Стенфорда також пропонує для вивчення курс "Створення ефективних онлайн та змішаних курсів" (https://online.stanford.edu/courses/gse-yopen-creating-effective-online-andblended-courses), причому зареєструватись на цей курс може будь-хто на безоплатній основі.

Університет систем Меріленду пропонує для вивчення курс "Інструкційний дизайн: цифрові медіа, нові інструменти та технології" (https://www.edx.org/course/instructional-design-digital-media-new-tools-andtechnology-1), де вивчаються такі питання: використання і реалізація Digital Media; використання інструментів від Web 2.0 до 3.0 і т.д.; використання Open Source Digital Media, Freeware i Shareware для підвищення якості навчання; аудіоінструменти та впровадження у навчання; інструменти електронного навчання та стратегія навчального дизайну; інструменти для редагування відео та інструктивна стратегія дизайну.

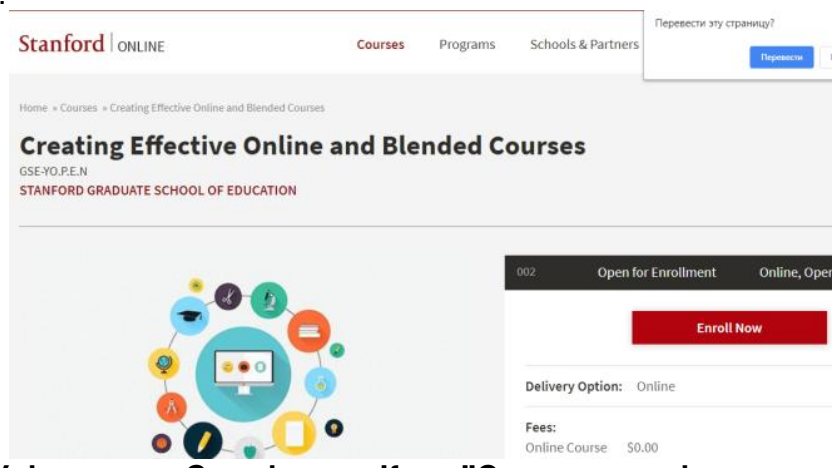

Рис. 3. Університет Стенфорда. Курс "Створення ефективних онлайн та змішаних курсів" 
Також у цьому університеті пропонується дисципліна "Інструкційний дизайн та технології" (https://www.edx.org/micromasters /instructional-design-technology), де студенти мають можливість: ознайомитись з сучасними теоріями навчання для розвитку онлайннавчання, навчальними моделями дизайну до розробки платформи онлайн-навчання, навчитись вибирати, оцінювати, інтегрувати або проектувати цифрові носії для підтримки онлайн навчання, впроваджувати онлайн навчання та застосовувати методи обміну даними до проектування та оцінки досвіду навчання.

Університет Пенсільванії пропонує свою дисципліну для вивчення "Вступ в онлайн та змішане навчання" (https://www.edx.org/course introduction-online-blended-teaching-pennx-volt101x), де студенти мають можливості ознайомитись 3: онлайн-навчанням, синхронним та асинхронним навчанням; використанням цифрових інструментів, змішаним навчанням, можливістю інтегрувати цифрові технології, інструменти та мережі, щоб розширити навчання та викладання; принципами та практиками дизайну в Інтернеті.

Масачусетський інститут технологій пропонує для вивчення дисципліну "Дизайн та розробка освітніх технологій" (https://www.edx.org/course/design-anddevelopment-of-educational-technolo gy-3).

У межах цього курсу вивчається: історія освітніх технологій, різні підходи до поглиблення навчання, активне навчання, симуляції, які можуть сприяти індивідуальному та спільному навчанню, різні типи оцінювання, методології дослідження та розробки освітніх інновацій.

У результаті аналізу закордонного досвіду було встановлено, що для студентів технічних спеціальностей, зокрема для майбутніх фрахівців з інформаційних технологій, було б доцільно ввести дисципліну "Освітні технології та навчання в цифрову епоху". У процесі фрахової підготовки майбутні фахівці з інформаційних технологій та в подальшому мають можливість: створювати курсові / дипломні проєкти педагогічного спрямування (розробка ПЗ навчального характеру, розробка навчальних ігор тощо), при роботі в IT-компаніях, при подальшому навчанні в аспірантурі тощо.

Дисципліна "Освітні технології та навчання в цифрову епоху" орієнтована на студентів спеціальностей 121 "Інженерія програмного забезпечення", 122 "Комп'ютерні науки", 123 "Комп'ютерна інженерія", 125 "Кібербезпека", 126 "Інформаційні системи та технології" та базується на засвоєнні майбутніми фахівцями основних понять та положень про освітні технології та технології навчання в цифрову епоху.

Дисципліна спрямована на студентів різного року навчання:

Студентів першого курсу бакалаврату - вступ в освітній процес в цифрову епоху, підготовка до ефрективного втілення концепції "навчання протягом всього життя" (life-long learning), ознайомлення із різновидами засобів ІКТ в освіті та підбір індивідуальних ефективних засобів різного призначення.

Студентів магістратури - підготовка до ефективного втілення 
концепції “навчання протягом всього життя" (life-long learning), ознайомлення із різновидами засобів ІКТ в освіті та підбір індивідуальних ефективних засобів різного призначення, реалізації спеціалізації з розробки освітніх технологічних та педагогічних рішень, а також підготовка до вступу на $\mathrm{PhD}$ програму відповідного напрямку.

Додаткові переваги, що надає вивчення цього курсу: формує знання, необхідні для початку дослідницької та прикладної діяльності в галузі "Інформаційно-комунікаційні технології в освіті"; надає підґрунтя для розвитку наукової діяльності в галузі "Інформаційно-комунікаційні технології в освіті" в університетах технічного спрямування; PR університетів технічного спрямування щодо поєднання навчальної, прикладної та соціальної функції.

Курс "Освітні технології та навчання в цифрову епоху" має своєю метою: 1) ознайомлення із основними поняттями; 2) загальний огляд технологій навчання; 3) детальний огляд інструментів для електронного навчання.

Навчальна дисципліна "Освітні технології та навчання в цифрову епоху" входить до циклу дисциплін за вибором студентів та доповнює знання з фундаментальних дисциплін для використання їх на практиці.

Засвоєння студентами основних положень цієї дисципліни поряд 3 освітньо-пізнавальним має і науково-прикладне значення на початковому етапі навчання і формування фахівця загалом.

Навчальною програмою передбачається: лекційні та лабораторні заняття, самостійна робота студентів; перевірка основних теоретичних знань та практичних умінь студентів за допомогою тестових завдань та контрольної роботи; складання заліку.

Основними труднощами при вивченні цієї дисципліни є багатоплановість матеріалу, який розглядається, і його значний обсяг. Тому успішне засвоєння курсу не можливе без регулярної самостійної роботи з літературою і творчого відношення до виконання практичних і лабораторних робіт.

Наведемо орієнтовний перелік тем, що пропонується для вивчення в межах дисципліни:

\section{І. Освітні технології та навчання в цифрову епоху}

1.Освітні технології та навчання в цифрову епоху: основні поняття, історія становлення, обґрунтування необхідності вивчати цей предмет.

2.Зарубіжний досвід вивчення технологій електронного навчання світовими університетами на технічних спеціальностях.

3.Види взаємодії комп'ютер -студент - викладач.

4.Технології навчання (традиційне, змішане навчання, перевернуте навчання, ігрове навчання, дистанційне навчання, синхронне та асинхронне навчання, адаптивне навчання, проєктне навчання тощо).

\section{II. Інструменти для електронного навчання}

1.Хмарні сервіси для спільної роботи над документами - заміна офісними додаткам (документи, електронні таблиці, презентації тощо).

2.Хмарні математичні сервіси. 
3.Ігрові симулятори, тренажери, навчальні ігри (принципи функціонування, принципи розробки та використання).

4.Хмарні сервіси для створення дистанційних курсів (Хмарні LMS, створення онлайн-тестуваня, матеріали: лекції, лабораторні, презентації, відео-матеріали, безкоштовні конструктори сайтів).

5.Масові відкриті онлайн курси (для використання вже готових і створення нових).

6.Засоби для вивчення програмування (хмарні компілятори, АСПЗ, CMS, безкоштовні хостинги).

7.Інтелектуальні карти.

8.Інструменти моделювання комп'ютерних мереж (Packet Tracker).

9.Віртуальні лабораторії.

10. Засоби спільної роботи для проєктної діяльності.

11. Засоби статистичної обробки даних.

Висновки. У результаті аналізу закордонного досвіду було встановлено, що для студентів технічних спеціальностей, зокрема для майбутніх фахівців з інформаційних технологій, було б доцільно ввести в навчальний план курс "Освітні технології та навчання в цифрову епоху". Це пояснюється тим, що в процесі професійної підготовки майбутні фахівці з інформаційних технологій мають підготуватися до: створення курсових / дипломних проєктів педагогічного спрямування (розробка ПЗ навчального характеру, розробка навчальних ігор тощо), до роботи в ITкомпаніях, подальшого навчання в аспірантурі тощо. Перспективами подальших досліджень $є$ впровадження курсу в освітній процес підготовки майбутніх фахівців 3 інформаційних технологій та перевірка ефективності.

\section{Література}

1.Биков В.Ю. Інформатизація загальноосвітньої і професійно-технічної школи України: концептуальні засади і пріоритетні напрями / В. Ю. Биков // Професійна освіта: педагогіка і психологія: Зб. наук. праць / За ред. І.Зязюна, Н. Ничкало. - Київ-Ченстохова: ВПШ, 2003. - Вип. IV. - С. 501-517.

2.Биков В.Ю. Сучасні завдання інформатизації освіти /В. Ю. Биков // Інформаційні технології і засоби навчання. - 2010. - №1 (15). Режим доступу до журналу: https://journal.iitta.gov.ua/

3.Биков В. Ю. Інформатизація освіти / В. Ю. Биков // Енциклопедія освіти України / Акад. пед. наук України; Головний ред. В.Г.Кремень. К. : Юрінком Інтер, 2008. - С. 360-362.

4. Гуржій А. М. Електронні освітні ресурси як основа сучасного навчального середовища загальноосвітніх навчальних закладів / А. М. Гуржій., В. В. Лапінський // Інформаційні технології в освіті : зб. наук. праць. - Вип. 15. -Херсон : ХДУ, 2013. - С. 3-5.

5.Жалдак М. І. Проблеми інформатизації навчального процесу в школі і в вузі / М. І. Жалдак // Сучасна інформаційна технологія в навчальному процесі : зб. наук. праць / [Редкол.: Шкіль М.І. (відп. ред) та ін.]. - К. : КДПІ, 1991. - С. 3-16.

6.Жук Ю. О. Роль засобів навчання у формуванні навчального середовища / Ю. О. Жук // Нові технології навчання. - 1998. - № 22. - С. 106-112.

7.Морзе Н. В. Система методичної підготовки майбутніх вчителів інформатики в педагогічних університетах: автореф. дис. на здобуття наук. ступеня д-ра пед. наук : спец. 13.00.02 "Теорія і методика навчання (інформатика)" / Н. В. Морзе. - К., 2003. - 39 с. 
8.Семеріков С. О. Хмарні технології навчання: витоки. / Семеріков С. О., Стрюк А. М., Маркова О.М [Електронний ресурс] // Інформаційні технології і засоби навчання. - 2015. - №2 (46). - C. 29-44. URL: http://journal.iitta.gov.ua/index.php/itlt/article/view/1234/916\#.VfFO4NLtmko.

9. Спірін О. М. Інформаційно-комунікаційні та інформатичні компетентності як компоненти системи професійно-спеціалізованих компетентностей вчителя інформатики /О.М. Спірін [Електронний ресурс] // Інформаційні технології і засоби навчання. - 2009. - №5(13). - URL: https://journal.iitta.gov.ua/index.php/ larticle/view/183/169.

10. Триус Ю. В. Комп'ютерно-орієнтовані методичні системи навчання математичних дисциплін у вищих навчальних закладах: автореф. дис. на здобуття наук. ступеня д-ра пед. наук: спец. 13.00 .02 "Теорія та методика навчання (математика)" / Ю. В. Триус. - К., 2005. - 48 с.

11. Яшанов С. М. Концептуальні засади проектування системи інформатичної підготовки майбутніх учителів в умовах компетентнісного підходу. / С. М. Яшанов // Міжнародний науковий форум: соціологія, психологія, педагогіка, менеджмент : збірник наукових праць. К. : ТОВ “НВП Інтерсервіс", 2015. - Вип. 17. - C. 181-190.

\section{References}

1. Bykov, V. (2003) Informatyzatsiia zahalnoosvitnoi i profesiino-tekhnichnoi shkoly Ukrainy: kontseptualni zasady i priorytetni napriamy [Informatization of a comprehensive and vocational-technical school of Ukraine: conceptual foundations and priority areas]. Profesiina osvita: pedahohika i psykholohiia: Zb. nauk. prats Professional education: pedagogy and psychology: Coll. Sciences. / Za red. I.Ziaziuna, N. Nychkalo. Kyiv-Chenstokhova: VPSh, 2003. Vyp. IV. S. 501-517. [in Ukrainian]

2. Bykov V.Yu. Suchasni zavdannia informatyzatsii osvity [Modern tasks of informatization of education]. Informatsiini tekhnolohii i zasoby navchannia. Information technologies and learninig tools. 2010. №1 (15). URL: https://journal.iitta.gov.ua/ [in Ukrainian]

3. Bykov V. Yu. Informatyzatsiia osvity [Informatization of education]. Entsyklopediia osvity Ukrainy - Encyclopedia of Education of Ukraine / Akad. ped. nauk Ukrainy; Holovnyi red. V.H.Kremen. K. : Yurinkom Inter, 2008. S. 360-362. [in Ukrainian]

4. Hurzhii A. M. Elektronni osvitni resursy yak osnova suchasnoho navchalnoho seredovyshcha zahalnoosvitnikh navchalnykh zakladiv [Electronic Educational Resources as a Basis of the Modern Educational Environment of Comprehensive Educational Institutions]. Informatsiini tekhnolohii v osviti : zb. nauk. prats. - Information Technologies in Education: Coll. Sciences. Vyp. 15. Kherson : KhDU, 2013. S. 3-5. [in Ukrainian]

5. Zhaldak M. I. Problemy informatyzatsii navchalnoho protsesu $v$ shkoli $i v$ vuzi [Problems of informatization of educational process in school and high school]. Suchasna informatsiina tekhnolohiia $v$ navchalnomu protsesi - Modern information technology in educational process:: zb. nauk. prats. K. : KDPI, 1991. S. 3-16. [in Ukrainian]

6. Zhuk Yu. O. Rol zasobiv navchannia u formuvanni navchalnoho seredovyshcha [The Role of Teaching Means in Forming the Learning Environment]. Novi tekhnolohii navchannia. - New Teaching Technologies. 1998. N22. S. 106-112. [in Ukrainian]

7. Morze N. V. Systema metodychnoi pidhotovky maibutnikh vchyteliv informatyky $v$ pedahohichnykh universytetakh [The system of methodological training of future teachers of informatics in pedagogical universities] : avtoref. dys. na zdobuttia nauk. stupenia d-ra ped. nauk : spets. 13.00.02 "Teoriia i metodyka navchannia (informatyka)" / N. V. Morze. - K., 2003. - 39 s. [in Ukrainian]

8. Semerikov S. O. Khmarni tekhnolohii navchannia: vytoky [Cloud technologies of learning: origins]. Informatsiini tekhnolohii i zasoby navchannia. - Information technologies 
and learning tools. 2015. N2 (46). S. 29-44. URL http://journal.iitta.gov.ua/index.php/itt/article/view/1234/916\#.VfFO4NLtmko. [in Ukrainian]

9. Spirin O. M. Informatsiino-komunikatsiini ta informatychni kompetentnosti yak komponenty systemy profesiino-spetsializovanykh kompetentnostei vchytelia informatyky [Information-communication and informational competences as components of the system of professional-specialized competences of the teacher of informatics]. Informatsiini tekhnolohii i zasoby navchannia - Information technologies and learning tools. 2009. №5 (13). URL : https://journal.iitta.gov.ua/index.php/ittl/article/view/183/169. [in Ukrainian]

10. Tryus Yu. V. Kompiuterno-oriientovani metodychni systemy navchannia matematychnykh dystsyplin u vyshchykh navchalnykh zakladakh [Computer-Oriented Methodical Systems of Teaching Mathematical Disciplines in Higher Educational Institutions]: avtoref. dys. na zdobuttia nauk. stupenia d-ra ped. nauk : spets. 13.00 .02 "Teoriia ta metodyka navchannia (matematyka)" / Yu. V. Tryus. - K., 2005. - 48 s. [in Ukrainian]

11. Yashanov S. M. Kontseptualni zasady proektuvannia systemy informatychnoi pidhotovky maibutnikh uchyteliv $v$ umovakh kompetentnisnoho pidkhodu [Conceptual bases of designing the system of informative training of future teachers in terms of competence approach]. Mizhnarodnyi naukovyi forum: sotsiolohiia, psykholohiia, pedahohika, menedzhment - International Scientific Forum: Sociology, Psychology, Pedagogy, Management: zbirnyk naukovykh prats. K. : TOV "NVP Interservis", 2015. Vyp. 17. S. 181-190. [in Ukrainian]

\section{АНОТАЦІЯ}

У статті проаналізовано закордонний досвід вивчення різних аспектів освітніх технологій та цифррової освіти в закладах вищої освіти. Зокрема, Carnegie Mellon University пропонує для випускників бакалаврату магістерську програму "Магістри освітніх технологій та прикладних навчальних наук", у межах якої для вивчення пропонує дисципліну "Дизайн навчальних ігор"; у Stanford Graduate School of Education пропонує для вивчення курс "Навчання, дизайн та технології"; Університет Стенфрорда студентами вивчається курс "Створення ефективних онлайн та змішаних курсів"; Університет систем Меріленду - такі курси, як "Інструкційний дизайн: цифрові медіа, нові інструменти та технології" та "Інструкційний дизайн та технології"; Університет Пенсільванії "Вступ в онлайн та змішане навчання"; Масачусетський інститут технологій - "Дизайн та розробка освітніх технологій".

У результаті аналізу закордонного досвіду було встановлено, що для студентів технічних спеціальностей, зокрема для майбутніх фрахівців з інформаційних технологій, було б доцільно ввести в навчальний план курс "Освітні технології та навчання в цифрову епоху". Це доцільно тому, що у процесі профресійної підготовки майбутні фахівці з інфоормаційних технологій мають навчитися: створювати курсові / дипломні проєкти освітнього спрямування (розробка ПЗ навчального характеру, розробка навчальних ігор тощо), підготування до роботи в IT-компаніях, подальшого навчання в аспірантурі тощо. Вивчення курсу готує студентів до майбутнього неперервного навчання з використанням цифрових технологій протягом життя. Дисципліна "Освітні технології та навчання в цифрову епоху" орієнтована на студентів спеціальностей 121 "Інженерія програмного забезпечення", 122 "Комп'ютерні науки", 123 “Комп'ютерна інженерія", 125 "Кібербезпека", 126 "Інфоормаційні системи та технології" та базується на засвоєнні студентами основних понять та положень про освітні технології, технології навчання в цифрову епоху. Наведено орієнтовний перелік тем. Обгрунтовано переваги, що надає вивчення цього курсу.

Ключові слова: освітні технології, цифрова епоха, навчання, інформатизація освіти, заклади вищої освіти. 